\title{
The Usefulness of Rapid Triple Test for Cardiac Marker in Forensic Paragnosis of Sudden Cardiac Death
}

\author{
Chae-Won $\operatorname{Lim}^{1}$, Jin-Gak Kim² \\ ${ }^{1}$ Department of Forensic Investigation Section, Jeonnam Provincial Police Agency, Muan, Korea \\ ${ }^{2}$ Department of Clinical Laboratory Science, Gwangyang Health Science University, Gwangyang, Korea
}

\section{심장표지물질 간이검사의 급성심장사 법의학적 사후진단 유용성에 관한 연구}

\author{
임채원 ${ }^{1}$, 김진각 ${ }^{2}$ \\ ${ }^{1}$ 전남지방경찰청 과학수사계, ${ }^{2}$ 광양보건대학교 임상병리과
}

\begin{abstract}
A sudden cardiac death (SCD) is defined as an unnatural sudden death caused by heart disease. To determine the cause of death, observation of the microscopic change in cardiac muscle tissue is suggested, rather than visual postmortem examination. However, this suggestion is time consuming to be applied in the field, is cost-ineffective, and is inconvenient. Therefore, the purpose of this study is to understand whether temporary inspection used to examine the cardiac marker (Myoglobin, CK-MB, CTn I) in postmortem blood via rapid cardiac triple test kit (which is used by clinics to diagnose patients with acute myocardial infarction) can effectively be utilized for the paragnosis of sudden, unnatural cardiac death. The results of postmortem examination and temporary investigation found that 23 groups (76.7\%), among the 30 experimental groups, were assumed to be non-traumatic sudden cardiac deaths, which indicated a positive response (according to comparison with forensic autopsy); 4 groups, among the 10 control groups, were assumed to be cerebrovascular disease, which indicated a negative response; 1 group was assumed to be alcoholic and drug poisoning, indicating a positive response; and 1 group was assumed to be oxygen deficiency due to suffocation, indicating a positive response. Hence, it was found that the level of sensitivity and specificity of cardiac marker's temporary inspection showed significant result, $76.7 \%$ and $80 \%$ respectively. Given this, temporary inspection can be effectively used for the paragnosis of sudden cardiac death when the medical history, situation of the site, and postmortem interval are considered together. With the result of precedent research on time of first revelation and extinction in blood, and difference in concentration over time progress according to the characteristic of cardiac marker's (myoglobin, CK-MB, cTn I) individual material, further research on concentration of cardiac marker per each post time needs to be conducted in order to estimate time science death (which is required to identify the cause of death and investigation).
\end{abstract}

Key words: Sudden cardiac death, Unnatural death, Rapid cardiac triple test, Paragnosis

This is an Open Access article distributed under the terms of the Creative Commons Attribution Non-Commercial License (http://creativecommons.org/licenses/by-nc/4.0) which permits unrestricted non-commercial use, distribution, and reproduction in any medium, provided the original work is properly cited.

Copyright @ 2017 The Korean Society for Clinical Laboratory Science. All rights reserved.
Corresponding author: Chae-Won Lim Department of Forensic Investigation Section, Jeonnam Provincial Police Agency, 28 Hugwangdae-ro-359-Gil, Samhyang-eup, Muan-gun 58564, Korea Tel: 82-61-289-2102 Fax: 82-61-289-2602 E-mail: dlacodnjs@hanmail.net

Received: April 14, 2017 Revised 1 ${ }^{\text {st. }}$ May 1, 2017 Revised $2^{\text {nd: }}$ : May 10, 2017 Revised 3 ${ }^{\text {rd. }}$ May 12, 2017 Accepted: May 12, 2017 


\section{서 론}

급성심장사는 건강하게 보이던 사람이 돌연 예기치 못하게 심장성 질환에 의해 사망하는 것으로, 목격자가 있는 경우는 증 상 발현 후 6 시간, 목격자가 없는 경우는 증상 발현 후 24 시간 이 내 사망한 것으로 정의하고 있다[1]. 급성심장사는 법의부검의 중요한 대상이 되며 우리나라에서도 법의부검에서 내인성급사 로 사망한 경우의 약 $60 \%$ 이상을 차지하고 있으며 대부분이 심 근 경색을 포함한 허혈성 심장질환에 기인하고 있다[2]. 급성심 장사는 대부분 심장관상동맥 질환에 의하여 사망을 하게 되는 데 이들의 의료기관 진료 내역을 당장에 확인할 수 없거나 병원 진료를 받지 않고 지내오면서 증상이 악화된 경우가 많기 때문 에 외표 검시만으로는 사인을 추정하기 어려운 경우가 많다 [1,3]. 변사사건 실무 현장에서 급성심장사로 판단하기 위해서 는 변사자의 병력과 사망 당시 현장상황에 대한 법의학적 조사 등 현장조사가 필요하다. 특히 교통사고 운전자에서 급성심근 경색에 의한 사망의 증명은 사건의 원인을 조사하는데 있어 보 험, 배상 등 민사적 문제와 더불어 형사적인 문제 등 법적인 문제 를 판단하는데 중요한 역할을 하므로 현장 검시전문가에 의한 자세한 조사 및 법의학적인 부검을 통하여 명확한 사인규명이 중요하다고 할 수 있다[4]. 경찰 검시조사관은 변사자 또는 변사 의 의심이 있는 시체에 대하여 범죄 혐의 유무를 판단하는 것을 목적으로 업무를 시행하며 변사자의 외표 검시와 전체적인 현 장상황을 종합하여 사인에 대한 추정 결론을 내리게 된다. 사인 추정에 대한 결론을 내릴 때에는 최초 발견자 및 목격자의 진술, 유족의 진술, 현장상황, 과거병력 등을 종합하여 판단한다[1,5]. 그러나 급성심장사의 경우 외표로 사망에 이를만한 법의학적인 소견이 발견되지 않는 경우가 많다. 급성심장사의 범주를 포괄 적으로 포함하고 있는 내인성급사의 경우 죽음을 예측하지 못 한 상태에서 갑자기 사망하게 되는 것으로 사람에 따라 사망경 과의 시기를 다르게 말하고 있다. 법의학에서는 대개 1 시간 정 도의 기준을 제시하고 있으며 대부분 법의부검을 통해 정확한 사인을 판단하여야 한다고 강조하고 있다[6,7]. 급성심장사의 경우 초기 변사현장에서 육안으로 확인 가능한 뚜렷한 변화가 없어 법의부검에서 효소 및 면역조직화학적 방법, 전자현미경 적 방법 등을 이용한 심근 조직의 형태학적 변화 관찰을 통한 사 후 진단이 제안되고 있다[8]. 그러나 시간과 비용, 편의성 등에 서 실제 변사사건 현장 외표 검시를 통한 신속한 사인추정으로 수사방향 설정 및 업무처리를 하여야 하는 실무현장에 적용하 는데 한계가 있다. 이에 본 연구에서는 임상병원 진단검사의학 과에서 급성심근경색 진단을 위한 경색된 심장 근육으로부터
유출되는 특이 심장표지물질myoglobin, CK-MB (creatine kinase-MB), cTn I (cardiac troponin I)을 측정하는[9] rapid cardiac triple test kit 간이 검사 방법을 이용하여 실제 변사사 건 현장에서 종합적인 주변 조사를 통하여 급성심장사로 추정 되는 변사자 30예에 적용, 법의부검 결과와 비교, 분석하였다. 이 결과를 바탕으로 실제 급성심장사 사후진단의 유용성 판단 및 심근 조직의 형태학적 변화를 통한 진단 방법이 내포하는 한 계점을 대체할 변사사건 초기 간단한 사인추정 검사방법 제시 로 신속한 변사사건 처리 등 유족에게 맞춤형 서비스 제공 및 경 찰 과학수사요원 및 경찰 검시조사관으로 하여금 올바른 초기 수사방향 설정에 도움을 주고자 하였다.

\section{대상 및 방법}

\section{1. 연구대상}

본 연구에 사용된 총 변사자 사후혈액 채취는 경찰청 과학수 사센터와 유족에게 연구계획서 제시 및 연구목적 외 다른 용도 로 활용하지 않겠다는 충분한 설명 과 활용 동의서를 받은 후 채 취, 실시하였다. 2016년 2월1일부터 2017년 1월31일까지 1년 동안 전남 관내에서 발생한 변사사건 현장에서 최초 발견자의 진술, 유족의 진술, 현장상황, 과거병력과 법의학적 외피 검시 소견, 심장표지물질 검사 결과 등을 종합하여 급성심장사로 추 정되는 사망한 지 5 72시간 내외의 부패되지 않은 상태로 국 립과학수사연구소에 법의부검을 감정 의뢰한 비외상성 변시체 30예를 실험군으로, 급성심장사가 아닌 기타 사망으로 추정된 비외상성 변시체 10예(뇌병변 추정 4예, 알코올 및 약물중독 4 예, 산소결핍성 질식사 2예)를 대조군으로 하여 총 40 예를 대상 으로 국립과학수사연구소 법의부검 결과와 비교, 분석 하였다 (Table 1).

Table 1. Cardiac triple test and forensic autopsy positivity between sudden cardiac death, and control group (non-traumatic)

\begin{tabular}{|c|c|c|c|}
\hline Case & SCD & Control & \\
\hline Result & $\begin{array}{c}\text { CTT } \\
\text { (F. autopsy) }\end{array}$ & $\begin{array}{c}\text { CTT } \\
\text { (F. autopsy) }\end{array}$ & Total \\
\hline Positive & $30(23)$ & $2(0)$ & $32(23)$ \\
\hline Negative & $0(7)$ & $8(10)$ & $8(17)$ \\
\hline Total & 30 & 10 & 40 \\
\hline
\end{tabular}

Abbreviation: SCD, sudden cardiac death; CTT, cardiac triple test; F. autopsy, Forensic Autopsy. 


\section{Rapid cardiac marker triple test}

심장표지물질 검사는 측정 한계치 CK-MB $16 \mathrm{U} / \mathrm{L}$, myoglobin $50 \mathrm{ng} / \mathrm{mL}$, cTn I $1 \mathrm{ng} / \mathrm{mL}$ 의 Rapid cardiac triple test kit (Humasis, Anyang, Korea)를 이용하여 측정하였다. 검사 방법은 발생장소 및 병원 장례식장 영안실에 임장하여 1회용주 사침을 이용, 급성심장사로 추정되는 변사자 가운데 손가락 끝 단에서 채취한 전혈을 키트 내 검체 적하 부위에 2 3방울 적하 하여 15분 후 반응 결과를 판독하였다[10]. rapid cardiac triple test kit의 검사 판정 매뉴얼의 경우 키트의 반응 부위 대 조선만 적색선이 한 줄로 나타나는 경우 음성, 대조선과 함께 나 타나는 반응선 출현 양상에 따라 항목 별 양성으로 판정하는 것 으로 되어 있으나, Figure 1과 같이 본 실험에서는 대조선과 함 께 3가지 심장표지물질 반응선이 모두 나타나는 경우 양성으로 판정한 후[11] 현장상황, 주변조사, 과거병력, 내인성급사 법의 학적 시체현상 등을 종합적으로 참고하여 급성심장사로 의심 추정하여 법의부검 결과와 비교하였다.

\section{3. 사후경과 시간의 추정}

사후경과 시간은 실험군, 대조군 모두 병원 후송 전 이미 사망 한 경우는 최초 발견자, 사망 전 마지막 목격자 진술, 출동 119 구급일지, 경찰 및 검시조사관의 시체현상에 따른 사망시간 추 정 결과 등을 참고하여 추정하였으며, 병원 후송중 또는 도착 후

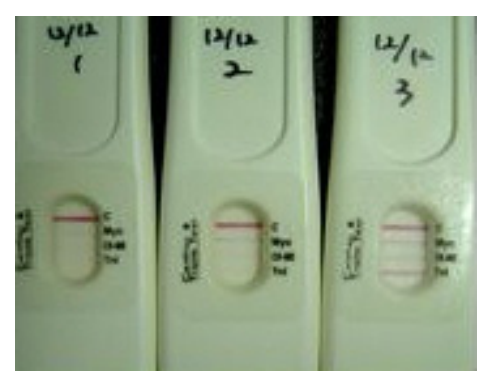

Figure 1. Humasis cardiac triple test rapid assay kit shows positive reaction of the postmortem blood sample.

Table 2. Results of cardiac marker triple test control case

\begin{tabular}{lccc}
\hline \multicolumn{1}{c}{ Case of death } & $\begin{array}{c}\text { PMI } \\
\text { (hours) }\end{array}$ & $\begin{array}{c}\text { No. of } \\
\text { case }\end{array}$ & $\begin{array}{c}\text { No. of } \\
\text { positive } \\
\text { case }\end{array}$ \\
\hline Brain lesion & $<24$ & 4 & 1 \\
Alcohol\&Drug poisoning* & $<24$ & 4 & 0 \\
Oxygen deficiency of suffocation & $<24$ & 2 & 1 \\
\hline
\end{tabular}

Abbreviation: PMI, postmortem interval.

*Agrichemical\&sleeping pill.
사망한 경우는 증상이 발현하여 사망할 때까지의 시간을 유족 등 최초 목격자 진술, 출동 119 구급일지, 병원 진료기록, 경찰 검시조사관의 변사조사결과보고서 등을 참고하여 추정하였다 (Table 2, 3).

\section{4. 심폐소생술 실시에 따른 영향}

심폐소생술 실시 여부는 최초 출동 119 구급일지, 병원 도착 후 기록된 응급실 진료 기록을 참고하였으며, 기록이 없는 경우 는 경찰 검시조사관의 변사자 조사결과보고서 및 법의부검 결 과를 참고하여 외표 및 내부검사에서 심폐소생술 유무를 확인, 심폐소생술 실시에 따라 나타나는 결과를 측정하였다(Table 4).

\section{결 과}

\section{1. 심장표지물질 간이 검사와 법의부검 결과의 비교}

Humasis cardiac triple test kit를 이용하여 실시한 심장표 지물질 간이 검사 결과 양성의 결과를 나타내어 급성심장사군 으로 추정한 30 예 중 23예(76.7\%)에서 법의부검 결과 급성심장 사 양성 결과를 보였다. 대조군에서는 10 예 중 심장표지물질 간 이 검사 결과 2 예 $(20.0 \%)$ 에서 양성의 결과를 보였으나, 법의부 검 결과 모두 급성심장사 음성의 결과를 보였다.

심장표지물질 간이 검사의 민감도는 $76.7 \%$, 특이도는 $80.0 \%$ 로 나타났다(Table 1). 비손상성 대조군의 경우 심장표지

Table 3. Results of forensic autopsy in sudden cardiac death 30 case

\begin{tabular}{|c|c|c|}
\hline Case of death & PMI (hours) & No. of case \\
\hline \multirow[t]{2}{*}{ Acute myocardial infarction } & $<24$ & 10 \\
\hline & $\geq 24$ & 1 \\
\hline \multirow{2}{*}{$\begin{array}{l}\text { Ischemic heart disease due to } \\
\text { coronary atherosclerosis }\end{array}$} & $<24$ & 7 \\
\hline & $\geq 24$ & 1 \\
\hline \multirow[t]{2}{*}{ Dilated cardiomyopathy } & $<24$ & 3 \\
\hline & $\geq 24$ & 1 \\
\hline \multirow[t]{2}{*}{ Brain lesion } & $<24$ & 3 \\
\hline & $\geq 24$ & 1 \\
\hline \multirow[t]{2}{*}{ Unknown or etc } & $<24$ & 3 \\
\hline & $\geq 24$ & 0 \\
\hline
\end{tabular}

Abbreviations: See Table 2.

Table 4. Cardiac marker triple test positivity 16 case of cardiopulmonary resuscitation

\begin{tabular}{|c|c|}
\hline Cardiac marker triple test & No. of case $(\%)$ \\
\hline Positive & $14(87.5)$ \\
\hline Negative & $2(12.5)$ \\
\hline Total & $16(100)$ \\
\hline
\end{tabular}


물질 간이 검사 결과 10 예 중 알코올 및 약물 중독 4 예 모두 음성 의 반응을 보였다. 뇌병변 4예 중 1 예, 산소결핍성질식사 2 예 중 1 예에서 양성의 결과를 보였으나, 법의부검 결과 모두 급성심장 사 음성으로 확인되었다(Table 2).

\section{2. 심장표지물질 간이 검사 결과 양성 30 예의 법의부검 결과}

총 30예 중 법의부검 결과와 일치한 23예의 경우 병리학적 분 류에 따라 급성심근경색 11 예, 관상동맥 질환에 의한 허혈성심 장질환 8예, 확장성 심근병증 4예로 급성심장사 확진으로 나타 났다. 간이검사 결과 양성의 결과를 보였으나, 법의부검 결과 음 성의 결과를 보인 7예의 경우 뇌 병변 4예, 불상 원인의 청장년 급사증후군 추정 및 기타 3예로 나타났다(Table 3).

\section{3. 급성심장사군의 사후경과 시간에 따른 심장표지물질 간이 검사 결과}

급성심장사군으로 추정한 총 30 예 중 법의부검 결과 급성심 장사양성의 결과와 일치한 23 예 중 사후 24 시간 이전에 간이 검 사를 실시한 26예에서 20예(76.9\%) 양성, 24시간 이후에 실시 한 4예 중 3예(75.0\%)에서 양성의 결과를 보였다(Table 3).

\section{4. 심폐소생술 실시에 따른 심장표지물질 간이 검사 결과}

간이 검사 결과 양성, 심폐소생술을 실시한 16 예 중 법의부검 결과 14예(87.5\%)에서 양성, 2예(12.5\%)에서 음성을 보였으 나, 음성 2예의 경우 법의부검 결과 뇌 병변, 청 - 장년 급사증후 군 등 기타 결과의 예로 심폐소생술 실시 여부가 간이 검사에 큰 영향은 미치지 않는 것으로 나타났다(Table 4).

\section{고 찰}

급성심장사는 건강한 사람이 갑자기 돌연 예기치 못한 심장 관상동맥질환에 의한 급성심근경색이나 허혈성 심장질환에 기 인하여 사망하는 것으로 법의부검에서 내인성급사의 약 $60 \%$ 이 상을 차지하고 있다[1,2] 급성 심근경색이나 허혈성 심장질환 발한 직후 심장근육 손상에 의한 변성 및 파괴로 혈액 내 노출되 는 대표적인 심장표지물질은 myoglobin, CK-MB, cTn I 또는 cTn T 등으로 알려져 있다[9,11,20]. 심장표지물질의 경우 첫 발병 직후 초기에 나타나는 심장표지물질 myoglobin, $\mathrm{CK}-\mathrm{MB}$ 와 확정적인 판단을 할 수 있는 심장표지물질로 cTn I 또는 cTn $\mathrm{T}$ 를 동시에 빠른 시간 안에 검사하여야 심근손상을 확인할 수 있다[18,20].

현재 경찰 과학수사에서는 변사 현장이나 영안실에서 외표
검시만으로 사인을 가릴 수 없는 경우가 빈번하여 법의부검에 서 심근 조직의 형태학적 변화 관찰을 통한 사후 진단을 하고 있 다. 그러나 시간과 비용, 편의성 등에서 실제 신속한 사인추정으 로 수사방향 설정 및 업무처리를 하여야 하는 변사사건 실무현 장에 적용하는데 한계가 있다. 이러한 형태학적 진단의 시간 및 비용의 한계를 극복하기 위해 임상 환자에게 적용하던 생화학 적 검사를 부검 진단에 응용 $[3,4,12]$ 한 시도의 초기에는 CTn I 를 사후 혈액에서 검출하는데 중점을 두어 급성심장사군에서 의미 있게 높았다는 결과를 보고하기도 하였다[12]. 그러나 이 러한 방법은 원심분리 후 사후 혈액을 고가의 장비를 이용하여 분석해야하는 등 시간과 경비 면에서 실제 현장에 적용하는데 어려움이 있다. 또한 심근 손상시 혈액으로 유리되어 혈청에서 검출될 경우 심근의 허혈성 손상과 관련되어 있다는 CTn T 경우 민감도와 특이도가 높은 혈중 cTn T 검사를 통한 심장 질환 환 자를 분류하고 위험도를 예측하는데 이용되고 있다[13,14]. 특 히 신속한 검사가 필요한 응급상황에서는 검사실을 거치지 않 고 전혈을 이용하여 즉시 혈중 cTn T를 측정할 수 있는 방법이 개발되어 심근의 허혈성 손상을 정확하게 검사할 수 있다는 것 을 보여주었다[15]. 임상에서는 급성 심근경색이나 허혈성 심 장질환 발한 직후 심장근육 손상에 의한 변성 및 파괴로 혈액 내 노출되어 높은 민감도와 특이도를 가지면서 빠른 시간 안에 분 석 가능한 심장표지물질 myoglobin, CK-MB, cTn I을 측정함 으로써 심근손상 여부를 확인, 진단을 하고 있다[9,20]. 실제 Kratz 등[11]은 임상에서 급성심근경색 양성 예측률은 myoglobin, CK-MB, cTn I 3가지 심장표지물질 중 1가지 표지 물질 약 $10.0 \%, 2$ 가지 표지물질 $17.0 \sim 33.0 \%$ 의 양성 예측률보 다 3 가지 심장표지물질을 검출했을 때 약 $76.0 \%$ 의 높은 양성 예 측률을 보고하였다. 본 연구에서도 rapid triple cardiac marker test kit를 이용하여 3가지 심장표지물질을 간이 검사 후 법의부검 결과와 비교, 분석한 결과는 Kratz 등[11]의 결과와 유사하게 대조군의 결과에 비해 급성심장사 추정군의 $76.7 \%$ 에 서 양성(민감도 $76.7 \%$, 특이도 $80.0 \%$ )으로 나타났다. 사후 부 패가 진행되지 않은 급성심장사 추정 변사자의 경우 사후경과 시간 24 시간 이내 및 심폐소생술 실시에 따른 영향이 크게 없는 것으로 나타나 급성심장사의 사후 혈액에서 심장표지물질 myoglobin, CK-MB, cTn I의 존재를 비교적 유용하게 검출할 수 있다는 것을 보여주었다. 이러한 결과는 변사사건 현장에서 과거병력, 현장상황 및 사후시간 등을 종합적으로 고려하여 사 후 급성심장사의 의심, 추정 진단에 보조적 방법의 하나로 유용 하게 이용될 수 있을 것으로 판단된다.

심장표지물질 myoglobin, CK-MB, cTn I 간이검사를 위한 
rapid triple cardiac marker test의 원리는 gold sol particle을 가진 이중 monoclonal antibody에 기초하고 있으며, 민감도 는 94.9\%로 골격근 유래 심장표지물질과의 교차반응은 0.01\% 이하인 것으로 알려져 있다[16]. cTn T 간이검사의 유용성을 연 구한 김 등[8]의 연구결과를 보면 급성심장사군에서 $68.6 \%$ 의 양성을 보여 사후에 심근허혈성 손상의 표지자인 cTn T 간이검 사결과가 급성심장사추정에 유용하다고 보고하며 사후경과시 간이 증가할수록 유의성이 감소하므로 급성심장사의 진단에 보 조적으로 사용하여야 한다고 하였다. Cina 등[10]의 결과를 보 면 심장질환과 관련된 사망 20예 중 17예(85.0\%)에서 양성으로 좀 더 높게 보였으며, 비심장성 대조군에서는 $30.0 \%$ 이하에서 양성을 보여 통계학적으로 의미가 있는 차이가 있었다고 보고 하고 있다. 이러한 결과는 본 연구와 Cina 등[10]의 연구에서는 변사사건 발생 후 사후 경과 시간이 얼마 되지 않은 변사자의 사 후 외표 검시를 하면서 대퇴 및 쇄골하 정맥에서 채취한 말초혈 액 또는 손가락 끝단에서 채취한 전혈을 대상으로 검사를 하였 으며, 김 등[8]의 연구에서는 부검 시 사후 심장 혈액을 대상으로 하였기 때문에, 측정 당시 사후경과시간 연장 및 혈액 종류의 차 이에 일부 기인한 것으로 추정된다.

본 연구에서 심장표지물질 간이 검사 시험 결과 양성의 결과 를 나타낸 23예의 급성심장사군의 법의부검 결과를 보면 급성 심근경색 11 예, 관상동맥질환에 의한 허혈성심장질환 8 예, 확 장성 심근병증 4 예의 경우로 모두 급성심장사에 의한 사망으로 나타났다. 이는 병리학적 분류 결과 직접적인 사망 원인에 차이 는 있으나, 법의학적 관점에서 모두 급성심장사로 판정하는 경 우이다. 그러므로 심장근육 변성으로 혈액 내 노출되는 대표적 인 심장표지물질 Myoglobin, CK-MB, cTn I 등을 생화학적 검 사 등을 통해 급성심장질환을 진단하는 응급실 등 임상병원에 서의 진단원리[11]와 동일하게 변사사건 현장에 급성심장사의 법의학적 사후 추정 진단의 보조적 한 방법으로 적용하여도 될 것으로 생각된다. 실제 박 등[17]은 병원 도착 전 사망환자에서 정확한 사망원인을 규명하기 위해서는 부검을 시행하여야 되 나, 실시하기 어려운 상황에서 응급실에서의 사후 혈액검사에 이미 개발되어 있는 심장효소 선별검사 키트를 사용하여 나타 나는 사망 당시 혈중 농도 및 결과를 적용하여 사인 결정에 큰 도 움이 되도록 할 수 있다고 보고하였다. 또한 병원 도착 전 사망한 경우 임상에서 급성심장사로 의심은 되나, 유족들의 입장에서 보면 사후 유족의 동의를 받기 어렵고, 검사비용, 건강보험 삭감 등의 문제로 응급실 내에서 사후 검사에 어려운 사례가 많이 보 고되고 있다[17].

이에 본 연구에서 나타난 결과를 기초로 하여 목격자 진술, 시
체현상, 현장조사, 과거병력, 119 출동기록, 병원 진료기록 등 을 참고하여 급성심장사로 추정되는 사건에 심장표지물질 간이 검사 방법을 보조적 추정 방법의 하나로 실시할 경우 시간과 비 용, 편리성 등 문제점 해결에 도움이 될 것으로 생각된다. 이는 정확한 사망원인 추정과 수사를 통한 불필요한 부검 배제 등 경 찰 과학수사요원과 검시조사관에게는 신속한 업무처리 기회 제 공을 통한 내부만족도 향상, 유족들에게는 만족할 만한 신속한 사건처리 결과를 제공하여 경찰과학수사에 대한 신뢰도 증대에 기여할 수 있을 것으로 생각되어진다. 향후 심장표지물질 myoglobin, CK-MB, cTn I 등의 개별물질 특성에 의한 혈액 내 최초 발현 및 소멸시간, 시간 경과에 따른 농도 차이 등에 대한 선행연구 결과[18-20]를 기초로 하여 사망원인 규명 등 사건 해 결에 필요한 사후경과시간 추정을 위한 사망 후 시간대 별 심장 표지물질 농도에 대한 추가적인 연구가 계속 되어야 할 것으로 생각된다.

\section{요 약}

급성심장사는 돌연 예기치 못한 심장질환에 의해 갑자기 사 망하는 것으로, 법의부검 실시 전 초기 변사현장에서 외피 검시 과정 중 육안적으로 법의학적 사인 추정을 위한 명확한 소견 관 찰이 어려운 점으로 인해 법의부검에서 심근 조직의 현미경적 변화 관찰을 통한 진단이 제안되고 있다. 그러나 검사시간, 비 용, 편의성 등 변사사건 현장 외표 검시를 통한 사인추정 실무현 장에 적용하는데 문제점을 드러내고 있다. 이에 본 연구에서는 임상 병원 진단검사의학에서 급성심근경색 환자의 진단 검사에 이용하는 심장표지물질 간이 검사 키트를 이용하여 사후 혈액 에서 심장표지물질 myoglobin, CK-MB, cTn I를 측정하는 간 이 검사가 내인성급사인 급성심장사를 사후 진단하는데 유용하 게 이용될 수 있는지를 알아보고자 하였다. 외피 검시 및 간이검 사 결과 비외상성 급성심장사로 추정되는 실험군 30 예를 법의 부검 결과와 비교한 결과 23예(76.7\%)에서 양성, 대조군 10예 중 뇌혈관질환 추정 4 예 모두 음성, 알코올 및 약물 중독 1 예, 산 소결핍 질식사 1 예에서 양성을 보였다. 심장표지물질 간이 검사 의 민감도와 특이도는 각각 $76.7 \%, 80.0 \%$ 의 유의한 결과를 보 여 변사사건 현장에서 변시체의 과거병력, 현장상황 및 사후시 간 등을 종합적으로 고려하여 사후 급성심장사의 의심, 추정 진 단에 보조적 방법의 하나로 유용하게 이용될 수 있을 것으로 사 료된다. 향후 심장표지물질(myoglobin, CK-MB, cTn I)의 개 별물질 특성에 의한 혈액 내 최초 발현 및 소멸시간, 시간 경과에 따른 농도 차이 등에 대한 선행연구 결과를 기초로 사망원인 규 
명 등 사건 해결에 필요한 사후경과시간 추정을 위한 사후 시간 대 별 심장표지물질 농도에 대한 추가적인 연구가 계속 되어야 할 것이다.

\section{Acknowledgements: None \\ Funding: None \\ Conflict of interest: None}

\section{REFERENCES}

1. Kim HS, Choi Mj, Sung HY, Kim SY, Park SW. Study on postmortem investigation for coronary artery sclerosis (CAS). Korean Journal of Scientific Criminal Investigation. 2011;5(4): 352-359.

2. Huh GY, Ahn YW, Kim YJ, Kim SJ, Oh SP, Kim KH, et al. A statistic analysis on forensic autopsy in Busan area in 2006: The Institute of Forensic Medicine in Pusan National University. Kor J Leg Med. 2007;31(1):1-9.

3. Cina SJ, Thompson WC, Fischer JR Jr, Brown DK, Titus JM, Smialek JE. A study of various morphologic variables and troponin I in pericardial fluid as possible discriminators of sudden death. Am J Forensic Med Pathol. 1999;20(4):333-337.

4. Osuna E, Perez-Carceles MD, Alvarez MV, Noguera J, Luna Al. Cardiac troponin I (cTn I) and the postmortem diagnosis of myocardial infarction. Int J Leg Med. 1998;111(4):173-176.

5. Lee SD, Lee TS. An analysis of 69 sudden cardiac death. Kor J Leg Med. 1996;20(1):82-88.

6. Kang SM, Lee WT, Lee HY, Seo JS, Choi YS, Kwon IH, et al. An analysis on the normal and normal hearts in adult sudden cardiac death. Kor J Leg Med. 2000;24(2):37-44.

7. Katus HA, Remppis A, Looster S, Hallermeier K, Scheffold T, Kubler W. Enzyme-linked immunoassay of cardiac troponin T for the detection of acute myocardial infarction in patients. $\mathrm{J}$ Mol Cell Cardiol. 1989;21(4):1349-1353.

8. Kim YJ, Ahn YW, Jo GR, Lee SY, Kim KH, Huh GY. Usefulness of rapid test for cardiac troponin $\mathrm{T}$ in postmortem diagnosis of sudden cardiac death. Kor J Leg Med. 2008;32(1):6-12.

9. Choi WS, Kim SC, Choo SK. Effectiveness of cardiac markers and blood chemistry analysis in detecting acute myocardial infarction. Kor J Clin Lab Sci. 2003;35(1):22-28.

10. Cina SJ, Brown DK, Smialek JE, Collins KA. A rapid postmortem cardiac troponin T assay. Am J Forensic Med Pathol. 2001; 22(1):173-176.

11. Kratz A, Januzzi JL, Lewandrowski KB, Lewandrowski EL. Positive predictive value of a point of care testing strategy on first-draw specimens for the emergency department-based detection of acute coronary syndromes. Arch Pathol Lab Med. 2002;126(12):1487-1493.

12. Cina SJ, Li DJ, Chan DW, Boitnott JK, Hruban RH, Smialek JE. Serum concentrations of cardiac troponin I in sudden death: a pilot study. Am J Forensic Med Pathol. 1998;19(4):324-328.

13. Ravkilde J, Nissen H, Horder M, Thygesen K. Independent prognostic value of serum creatine kinase isoenzyme MB mass, cardiac troponin $\mathrm{T}$ and myosin light chain levels in suspected acute myocardial infarction: analysis of 28 months of follow-up in 196 patients. J AM Coll Cardiol. 1995;25(3):574-581.

14. Wu AH, Abbas SA, Green S, Pearsall L, Dhakam S, Azar R, et al. Prognostic value of cardiac troponin $\mathrm{T}$ in unstable angina pectoris. AM J Cardiol. 1995;76(12):970-972.

15. Müller-Bardorff M, Freitag H, Scheffold T, Remppis A, Kübler W, Katus HA. Development and characterization of a rapid assay for bedside determinations of cardiac troponin T. Circulation. 1995;92(10):2869-2875.

16. Christian WH, Britta UG, Christopher H, Georg K, Jürgen B, Thomas M. Emergency room triage of patients with acute chest pain by means of rapid testing for cardiac Troponin $\mathrm{T}$ or Troponin I. N Engl J Med 1997;337(23):1648-1653.

17. Park JH, Kim YJ, Ham SH, Yeom SR, Ahn R, Ha HI. Forensic analysis of the cause of death and death on arrival of patients at the emergency room. Kor J Leg Med. 2013;37(1):14-18.

18. Kim KD. Tests for Acute Coronary Syndrome. Yeongnam Univ J Med. 2001;18(1):13-29.

19. Jaffe AS, Babuin L, Apple FS. Biomarkers in acute cardiac disease: the present and the future. J AM Coll Cardiol. 2006; 48(1):1-11.

20. Apple FS, Christenson RH, Valdes R, Andriak AJ, Berg A, Duh $\mathrm{SH}$, et al. Simultaneous rapid measurement of whole blood myoglobin, creatine kinase $\mathrm{MB}$, and cardiac troponin I by the triage cardiac panel for detection of myocardial infarction. Clin chem. 1999;45(2):199-205. 